\title{
Spatial distribution in sediment characteristics and benthic activity on the northwestern Black Sea shelf
}

\author{
Jeroen W. M. Wijsman ${ }^{1, *}$, Peter M. J. Herman ${ }^{1}$, Marian-Traian Gomoiu ${ }^{2}$ \\ ${ }^{1}$ Netherlands Institute of Ecology, Centre for Estuarine and Coastal Ecology, PO Box 140, 4400 AC Yerseke, The Netherlands \\ ${ }^{2}$ National Institute of Marine Geology and Geo-ecology, Constanta branch, Mamaia 304, RO-8700 Constanta, Romania
}

\begin{abstract}
The influence of the River Danube as a major source of nutrients and suspended solids to the continental shelf of the Black Sea has been analyzed. In the framework of the EC project EROS2000, sediment cores from 33 stations on the northwestern continental shelf were sampled in August 1995. Spatial patterns in structural sediment characteristics, macrobenthos composition and benthic mineralization rates were examined using ordination techniques. Three general areas could be distinguished according to the distribution of abiotic sediment characteristics and macrobenthos community: (1) The area just in front of the Danube Delta where large amounts of nutrients and suspended solids are discharged. High sedimentation rates of fine-grained sediments and high benthic mineralization rates characterized this area. The macrobenthos community was dominated by deposit feeders. (2) The northern part of the continental shelf where an anticyclonic gyre is located. The majority of the Danube discharges are transported to this region. This area was characterized by low sedimentation rates. However, the deposited material contained a larger fraction of fresh organic matter compared to the delta area, resulting in high benthic mineralization rates. Suspension feeders dominated the macrobenthos community. (3) The southern part of the continental shelf was characterized by low sedimentation rates and low rates of benthic mineralization. In this area suspension feeders dominated the macrobenthos community. Oxygen fluxes into the sediment ranged between 2 and $52 \mathrm{mmol} \mathrm{O}_{2} \mathrm{~m}^{-2} \mathrm{~d}^{-1}$ (average $21 \mathrm{mmol} \mathrm{O} \mathrm{m}^{-2} \mathrm{~d}^{-1}$ ) decreasing with water depth. Macrobenthos accounted for $20 \%$ of the total benthic oxygen consumption. In the northern part of the continental shelf and in the coastal stations, microorganisms, and micro- and meiobenthos dominated benthic community respiration, while macrobenthos became relatively more important in terms of oxygen consumption in the southern part of the continental shelf.
\end{abstract}

KEY WORDS: Black Sea - Danube - Macrobenthos $\cdot$ Benthic oxygen flux Ordination $\cdot$ Benthic-pelagic coupling

\section{INTRODUCTION}

The Black Sea is the largest $\left(537000 \mathrm{~km}^{3}\right)$ permanently stratified marine basin of the world (Sorokin 1983). A strong pycnocline at 150 to $200 \mathrm{~m}$ depth forms a barrier for intermixing between anoxic, hydrogen sulfide containing deep water and oxic, productive surface water (Murray et al. 1989, Kempe et al. 1990, Lyons et al. 1993). The area shallower than $200 \mathrm{~m}, 27 \%$ of the total area, is mainly located in the northwest. The northwestern continental shelf, here defined as

•E-mail: wijsman@cemo.nioo.knaw.nl the area shallower than $200 \mathrm{~m}$, north of Varna and west of Sevastopol, covers an area of $70000 \mathrm{~km}^{2}$ (Fig. 1). Since the bottom water in the abyssal part of the Black Sea is anoxic, most benthic fauna is restricted to the continental shelf area. Also, many pelagic species depend on the continental shelf for foraging and spawning (Tolmazin 1985a, Niermann et al. 1994).

The ecosystem of the continental shelf is influenced by the major rivers, the Danube, the Dniester and the Dnieper, which together discharge more than $250 \mathrm{~km}^{3}$ fresh water $\mathrm{yr}^{-1}$ in the $3000 \mathrm{~km}^{3}$ continental shelf (Tolmazin 1985b, Sapozhnikov 1992, Fabry et al. 1993). The River Danube accounts for $75 \%$ of the total river input into the northwestern continental shelf of the 


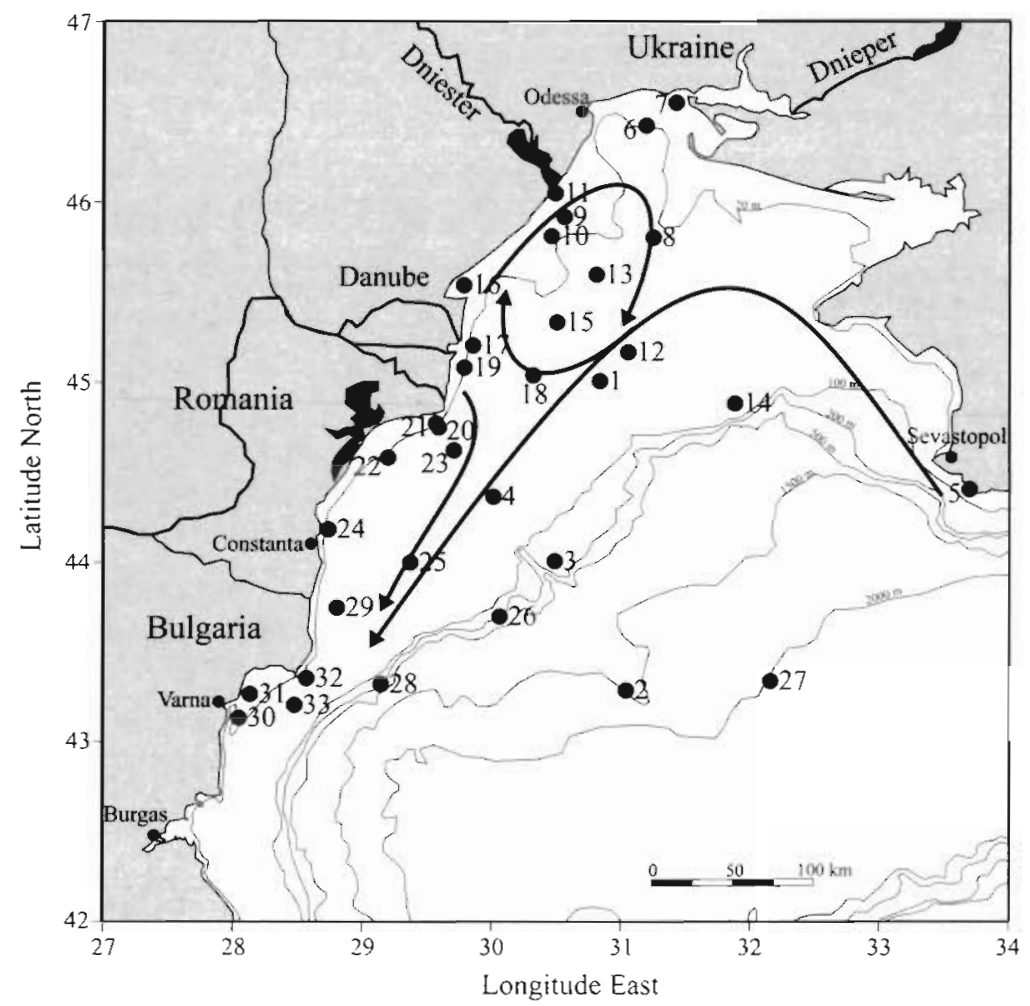

Fig. 1. Map of the study area in the northwestern part of the Black Sea with sampling stations. The arrows indicate the general circulation pattern based on the results of a high-resolution hydrodynamic model (M. L. Grégoire \& J. M. Beckers pers. comm.)

Black Sea and is a major source of pollutants, nutrients and organic matter (Popa 1993). Each year, the Danube discharges 45 to $50 \times 10^{6}$ t of suspended solids into the Black Sea (Popa 1993). Due to intensification of agricultural and industrial activities in the catchment areas, the input of nutrients and waste products has increased since the 1960s (Konovalov 1995). Construction of dams in the River Danube has changed the nutrient composition of the Danube discharges (Humborg et al. 1997). As a result, the silicate to nitrogen ratio on the continental shelf has decreased, resulting in a shift in phytoplankton community from a diatom dominated phytoplankton community to a community dominated by non-siliceous species, such as coccolithophores and flagellates (Cociasu et al. 1996. Humborg et al. 1997, Mihnea 1997).

During the 1970s and 1980s, the ecosystem of the Black Sea changed significantly at various levels (Gomoiu 1992, Mee 1992, Zaitsev 1993, Bologa et al. 1995, Leppäkoski \& Mihnea 1996). Many species disappeared or decreased in biomass, e.g. the macroalgae Phyllophora spp., the mussel Mytilus galloprovincialis (Zaitsev 1993) and fish species such as sturgeon and turbot (Gomoiu 1985a). Other species increased explo- sively in biomass, e.g. Mya arenaria (bivalve) (Gomoiu 1985b), the flagellate Noctiluca scintillans (Porumb 1992) and the jellyfishes Aurelia aurita (Gomoiu 1980) and Mnemiopsis leidyi (Mutlu et al. 1994).

It is assumed that these modifications of the ecosystem were essentially caused by changes in nutrient discharges through major rivers, particularly the Danube (Gomoiu 1992, Mee 1992, Cociasu et al. 1996, Humborg et al. 1997). The majority of the Danube output is transported to the north, where it forms an anticyclonic gyre (Oguz \& Malanotte-Rizzoli 1996, Grégoire et al. 1997, Grëgoire et al. 1999). From there the water is transported southward over the continental shelf (M. L. Grégoire \& J. M. Beckers pers. comm.). During the transportation, the composition of the watermass changes due to physical and biological processes. Sedimentation is a function of water column characteristics such as turbidity, current velocity and primary production. Sedimentation processes are reflected in the physico-chemical characteristics of the sediment such as grain-size distribution, organic carbon content, $\mathrm{C} / \mathrm{N}$ ratio and iron concentration. Fluxes from the water column to the sediment also influence early diagenetic processes (Henrichs 1992) and biomass of the macrobenthos (Rowe et al. 1991). Changes in the benthic community during a process of eutrophication (Pearson \& Rosenberg 1978, Weston 1990, Heip et al. 1995) show the sensitivity of the benthos to sedimentation, but since most interactions are complex and non-linear, the results are not always predictable. We hypothesize that if rivers can have such an impact on the ecosystem, the effect of the largest river, the Danube, must be visible in the spatial distribution of the biotic and abiotic sediment characteristics on the shelf.

In the framework of the EC project EROS-2000, the relationship between increased input of nutrients through the rivers and changes that occurred in the ecosystem of the Black Sea has been analyzed. The present paper focuses on the benthic part of the system. Structural sediment characteristics such as grain size and porosity that are indicative for the sedimentation regime and solid-phase constituents that are related to mineralization processes have been determined. The oxygen flux to the sediment has been measured as an estimation of the rate of benthic mineralization (Pamatmat 1971, Heip et al. 1995), and the contribution of macrobenthos in total sediment respira- 
tion has been calculated. Spatial variations in biogeochemical characteristics were compared with the distribution of macrobenthos in order to identify common patterns. These distribution patterns have been related to the geographic location of the plume of the Danube.

\section{MATERIAL AND METHODS}

Sampling sites. From 5 to 27 August 1995, 33 stations were sampled on the northwest continental shelf on the 48th cruise of the RV 'Professor Vodyanitsky' (Table 1). The weather was calm and relatively constant during this period. From CTD profiles, a seasonal temperature stratification of the upper water layers could be detected at all stations. Sediment was sampled with a Reineck box corer $(60 \times 30 \times 30 \mathrm{~cm})$ at all stations, except Stns 21 and 27 where only water samples were taken.

Sediment parameters. Sediment cores from Stns $1-6,11,12,14,16-20,22-26$ and $28-31$ were subsampled from the box corer with Plexiglas tubes (5.8 $\mathrm{cm}$ i.d., $50 \mathrm{~cm}$ length) and closed with silicon stoppers. The cores were sliced at several depth intervals: $0-0.5 ; 0.5-1 ; 1-1.5 ; 1.5-2 ; 2-3 ; 3-4 ; 4-5 ; 5-7$; $7-9 ; 9-11 ; 14-16$ and $19-21 \mathrm{~cm}$. The sediment was stored frozen in $50 \mathrm{ml}$ polycarbonate vials. Within 2 mo after sampling, the samples were dried by lyophylization. Water content was calculated from weight loss, and porosity was calculated from water content, assuming a sediment density of $2.55 \mathrm{~g} \mathrm{~cm}^{-3}$. The shell fraction was separated from the sediment by sieving over a $0.6 \mathrm{~mm}$ sieve. The $\mathrm{CaCO}_{3}$ content of the remaining sediment was determined through volumetric gas analysis after acidification of $0.4 \mathrm{~g}$ dry sediment with $10 \mathrm{ml}$ hydrochloric acid $(8 \mathrm{~N})$ (Scheibler method). Total carbonate concentration was defined as the sum of the dispersed $\mathrm{CaCO}_{3}$ content of the sediment and the shell remains of bivalves. It was assumed that the bivalve shell residues were mainly composed of carbonate. Total Fe and total Mn were determined with a Perkin Elmer atomic absorption spectrometer, and total $\mathrm{P}$ was determined by using spectrophotometry after microwave extraction with hydrochloric acid $(12 \mathrm{~N})$ and nitric acid (14 N) (Nieuwenhuize et al. 1991). Total iron content was expressed on a carbonate free basis $[[\mathrm{g} F \mathrm{Fe} / \mathrm{g}$ dry sediment $-\mathrm{g} \mathrm{CaCO}_{3}-\mathrm{g}$ shells)] $\times 100 \%$ \}. By correcting for carbonate content of the sediment, the iron content is made independent of dilution by $\mathrm{CaCO}_{3}$. Organic carbon and total nitrogen were determined with a Carlo Erba NA 1500 elemental analyzer, after in situ hydrochloric acid ( $8 \mathrm{~N}$ ) acidification to remove inorganic carbon (Nieuwenhuize et al. 1994). Grainsize distributions were determined using laser diffrac- tion with a Malvern particle sizer $(300 \mathrm{~mm}$ focal length) after removal of the organic matter and carbonates with peroxide $(10 \mathrm{~N})$ and hydrochloric acid $(1 \mathrm{~N})$.

Sediment community oxygen consumption (SCOC). SCOC was measured at Stns $1,3-6,11,12,14,16-20$, $22-26$ and $28-30$. Two Plexiglas core tubes $(10.3 \mathrm{~cm}$ i.d., $30 \mathrm{~cm}$ length) were used to measure SCOC. Directly after retrieving the box corer, the cores were gently pushed $15 \mathrm{~cm}$ into the sediment and closed with a lid. In general, 10 to $20 \mathrm{~cm}$ of bottom water was still present on top of the sediment during sub-sampling. Only at Stns 6, 22 and 29 did the box corer not contain enough bottom water. At these stations, bottom water, sampled by the GO-FLO rosette bottles, was added gently on top of the sediment with a siphon. Within 30 min after retrieval, the cores were sealed with Plexiglas lids with O-rings, containing a YSI 5739 oxygen electrode and a Teflon coated magnetic stirrer. The cores were incubated in the dark at in situ temperature

Table 1. Location, sampling date and water depth of the sampling stations

\begin{tabular}{|c|c|c|c|c|}
\hline Stn & $\begin{array}{l}\text { Geograph } \\
\text { Latitude }\end{array}$ & $\begin{array}{l}\text { Cal position } \\
\text { Longitude }\end{array}$ & $\begin{array}{l}\text { Sampling date } \\
\text { (1995) }\end{array}$ & $\begin{array}{l}\text { Water depth } \\
(\mathrm{m})\end{array}$ \\
\hline 1 & $45^{\circ} 00^{\prime} 23^{\prime \prime}$ & $30^{\circ} 49^{\prime} 55^{\prime \prime}$ & $06 \mathrm{Aug}$ & 57 \\
\hline 2 & $43^{\circ} 17^{\prime} 13^{\prime \prime}$ & $31^{\circ} 02^{\prime} 19^{\prime \prime}$ & $08 \mathrm{Aug}$ & 1536 \\
\hline 3 & $44^{\circ} 00^{\prime} 23^{\prime \prime}$ & $30^{\circ} 29^{\prime} 06^{\prime \prime}$ & $09 \mathrm{Aug}$ & 134 \\
\hline 4 & $44^{\circ} 21^{\prime} 55^{\prime \prime}$ & $30^{\circ} 00^{\prime} 32^{\prime \prime}$ & $10 \mathrm{Aug}$ & 69 \\
\hline 5 & $44^{\circ} 24^{\prime} 24^{\prime \prime}$ & $33^{\circ} 41^{\prime} 34^{\prime \prime}$ & $12 \mathrm{Aug}$ & 58 \\
\hline 6 & $46^{\circ} 25^{\prime} 28^{\prime \prime}$ & $31^{\circ} 11^{\prime} 15^{\prime \prime}$ & 13 Aug & 20 \\
\hline 7 & $46^{\circ} 33^{\prime} 02^{\prime \prime}$ & $31^{\circ} 25^{\prime} 07^{\prime \prime}$ & $13 \mathrm{Aug}$ & 12 \\
\hline 8 & $45^{\circ} 48^{\prime} 08^{\prime \prime}$ & $31^{\circ} 14^{\prime} 41^{\prime \prime}$ & $13 \mathrm{Aug}$ & 31 \\
\hline 9 & $45^{\circ} 55^{\prime} 04^{\prime \prime}$ & $30^{\circ} 33^{\prime} 24^{\prime \prime}$ & $14 \mathrm{Aug}$ & 17 \\
\hline 10 & $45^{\circ} 48^{\prime} 35^{\prime \prime}$ & $30^{\circ} 27^{\prime} 24^{\prime \prime}$ & $14 \mathrm{Aug}$ & 25 \\
\hline 11 & $46^{\circ} 02^{\prime} 58^{\prime \prime}$ & $30^{\circ} 29^{\prime} 11^{\prime \prime}$ & $14 \mathrm{Aug}$ & 12 \\
\hline 12 & $45^{\circ} 10^{\prime} 01^{\prime \prime}$ & $31^{\circ} 02^{\prime} 60^{\prime \prime}$ & $15 \mathrm{Aug}$ & 53 \\
\hline 13 & $45^{\circ} 35^{\prime} 47^{\prime \prime}$ & $30^{\circ} 48^{\prime} 17^{\prime \prime}$ & 15 Aug & 38 \\
\hline 14 & $44^{\circ} 52^{\prime} 58^{\prime \prime}$ & $31^{\circ} 52^{\prime} 35^{\prime \prime}$ & 16 Aug & 63 \\
\hline 15 & $45^{\circ} 19^{\prime} 57^{\prime \prime}$ & $30^{\circ} 29^{\prime} 59^{\prime \prime}$ & 17 Aug & 37 \\
\hline 16 & $45^{\circ} 32^{\prime} 18^{\prime \prime}$ & $29^{\circ} 46^{\prime} 34^{\prime \prime}$ & $17 \mathrm{Aug}$ & 16 \\
\hline 17 & $45^{\circ} 12^{\prime} 14^{\prime \prime}$ & $29^{\circ} 50^{\prime} 50^{\prime \prime}$ & $18 \mathrm{Aug}$ & 26 \\
\hline 18 & $45^{\circ} 02^{\prime} 19^{\prime \prime}$ & $30^{\circ} 18^{\prime} 56^{\prime \prime}$ & $18 \mathrm{Aug}$ & 45 \\
\hline 19 & $45^{\circ} 04^{\prime} 53^{\prime \prime}$ & $29^{\circ} 46^{\prime} 53^{\prime \prime}$ & 19 Aug & 21 \\
\hline 20 & $44^{\circ} 44^{\prime} 57^{\prime \prime}$ & $29^{\circ} 34^{\prime} 56^{\prime \prime}$ & 19 Aug & 25 \\
\hline 21 & $44^{\circ} 46^{\prime} 17^{\prime \prime}$ & $29^{\circ} 33^{\prime} 40^{\prime \prime}$ & 20 Aug & 8 \\
\hline 22 & $44^{\circ} 34^{\prime} 56^{\prime \prime}$ & $29^{\circ} 11^{\prime} 23^{\prime \prime}$ & $20 \mathrm{Aug}$ & 27 \\
\hline 23 & $44^{\circ} 37^{\prime} 20^{\prime \prime}$ & $29^{\circ} 42^{\prime} 03^{\prime \prime}$ & $20 \mathrm{Aug}$ & 49 \\
\hline 24 & $44^{\circ} 10^{\prime} 59^{\prime \prime}$ & $28^{\circ} 43^{\prime} 54^{\prime \prime}$ & $21 \mathrm{Aug}$ & 27 \\
\hline 25 & $43^{\circ} 59^{\prime} 57^{\prime \prime}$ & $29^{\circ} 21^{\prime} 54^{\prime \prime}$ & 22 Aug & 56 \\
\hline 26 & $43^{\circ} 41^{\prime} 50^{\prime \prime}$ & $30^{\circ} 03^{\prime} 30^{\prime \prime}$ & 22 Aug & 141 \\
\hline 27 & $43^{\circ} 20^{\prime} 21^{\prime \prime}$ & $32^{\circ} 09^{\prime} 15^{\prime \prime}$ & $23 \mathrm{Aug}$ & 1997 \\
\hline 28 & $43^{\circ} 19^{\prime} 14^{\prime \prime}$ & $29^{\circ} 08^{\prime} 21^{\prime \prime}$ & $24 \mathrm{Aug}$ & 123 \\
\hline 29 & $43^{\circ} 44^{\prime} 49^{\prime \prime}$ & $28^{\circ} 47^{\prime} 51^{\prime \prime}$ & 24 Aug & 51 \\
\hline 30 & $43^{\circ} 07^{\prime} 59^{\prime \prime}$ & $28^{\circ} 02^{\prime} 39^{\prime \prime}$ & $25 \mathrm{Aug}$ & 20 \\
\hline 31 & $43^{\circ} 15^{\prime} 57^{\prime \prime}$ & $28^{\circ} 07^{\prime} 47^{\prime \prime}$ & 25 Aug & 24 \\
\hline 32 & $43^{\circ} 21^{\prime} 16^{\prime \prime}$ & $28^{\circ} 33^{\prime} 58^{\prime \prime}$ & 25 Aug & 50 \\
\hline 33 & $43^{\circ} 12^{\prime} 18^{\prime \prime}$ & $28^{\circ} 28^{\prime} 24^{\prime \prime}$ & 26 Aug & 64 \\
\hline
\end{tabular}


in a thermostated bath for 4 to $8 \mathrm{~h}$. A magnetic stirrer mixed the bottom water continuously without visual disturbance of the sediment. Oxygen concentration and temperature of the overlying water were measured every $20 \mathrm{~s}$ and stored on a datalogger. The electrodes were calibrated with filtered seawater at various oxygen concentrations using Winkler titration (Parsons et al. 1984). Oxygen flux was determined using linear regression from the moment that in situ temperature was reached (after 1 to $1.5 \mathrm{~h}$ ). Enclosed incubations change the solute concentrations in the overlying water (Devol \& Christensen 1993, Duineveld et al. 1997a). Therefore, long time incubations change the concentration gradients and may, thus, influence the fluxes. To avoid this artifact only the initial, linear part of the curve was used to calculate the flux. A correction was applied for oxygen consumption by the probe and the bottom water through incubating nonfiltered bottom water without sediment. On average this correction was $1.4 \mathrm{mmol} \mathrm{O}_{2} \mathrm{~m}^{-2} \mathrm{~d}^{-1}(15 \mathrm{~cm}$ water column). All stations were sampled in duplicate from the same box corer, except Stns 1, 12, 16, 20 and 24 where only single cores could be incubated. After incubation, the cores from the incubators were sectioned into $2 \mathrm{~cm}$ slices and preserved in formaldehyde for macrobenthos analysis.

Macrobenthos. Macrobenthos was sampled at $30 \mathrm{sta}-$ tions on the continental shelf. At these stations, $8.6 \mathrm{~cm}$ i.d. cores were taken from the box corer down to 10-12 cm depth. On board, the samples were stained with Congo Red and preserved in buffered formaldehyde $(4 \%)$. In the laboratory, the samples were washed through $1.0,0.25$ and $0.125 \mathrm{~mm}$ mesh sieves. Macrobenthic animals were identified and wet weight, including shells, was determined. Biomass was converted to $g$ ash-free dry weight (AFDW) $\mathrm{m}^{-2}$ using conversion factors of Rumohr et al. (1987). For this study, only species larger than $1 \mathrm{~mm}$ were enumerated. Heterogeneity (Peet 1974) was calculated as Hill's diversity numbers (Hill 1973) of order 0, 1, 2 and $\infty . N_{0}=S_{i} N_{1}=\exp \left[-\sum p_{i} \ln \left(p_{i}\right)\right]_{i} N_{2}=1 / \sum\left(p_{i}^{2}\right) ; N_{\infty}=1 / p_{1}$ where $p_{i}(i=1,2, \ldots, S)=$ relative abundance of the $i$ th most dominant species (Heip et al. 1988, Soetaert et al. 1991).

Statistical analysis of data. The relationship between the sediment characteristics was investigated using Principal Components Analysis (PCA) (Jongman et al. 1987). The ordination was performed with the Systatpackage on the correlation matrix of the variables using the varimax rotation. The data presented in Table 2, with addition of the sediment community oxygen consumption (SCOC), were used for the PCA. A complete set of data was available for 21 stations.

Correspondence Analysis (CA) was applied on the species abundance matrix using the software package CANOCO (Ter Braak 1988, 1990). Stn 28 was excluded from the analysis since only 2 species were found at this station: the cnidarian Pachycerianthus imperator and the polychaete Heteromastus filiformis. The hydrozoan Obelia longissima and the polychaete Perinereis

Table 2. Sediment characteristics averaged over the top $21 \mathrm{~cm}$

\begin{tabular}{|c|c|c|c|c|c|c|c|c|c|c|c|}
\hline Stn & $\begin{array}{c}\text { Porosity } \\
\left(\mathrm{cm}^{3} \mathrm{~cm}^{-3}\right)\end{array}$ & $\begin{array}{l}\text { Med. grain size } \\
(\mu \mathrm{m})\end{array}$ & $\begin{array}{c}\text { Silt }<63 \mu \mathrm{m} \\
(\%)\end{array}$ & $\begin{array}{c}\mathrm{CaCO}_{3} \\
(\%)^{3}\end{array}$ & $\begin{array}{l}\text { Shells } \\
(\%)^{b}\end{array}$ & $\begin{array}{c}\text { Org. C } \\
(\%)^{a}\end{array}$ & $\begin{array}{c}\text { Total N } \\
\qquad(\%)^{\alpha}\end{array}$ & $\begin{array}{l}\text { C/N ratio } \\
\left.(\mathrm{mol} \mathrm{mol})^{-1}\right)\end{array}$ & $\begin{array}{c}\text { Total Fe } \\
(\%)^{c}\end{array}$ & $\begin{array}{c}\text { Total Mn } \\
(\% o)^{\circ}\end{array}$ & $\begin{array}{l}\text { Total P } \\
(\% \circ)^{\circ}\end{array}$ \\
\hline 1 & 0.79 & 15.67 & 99.38 & 42.97 & 44.73 & 2.71 & 0.31 & 10.25 & 3.45 & 0.71 & 0.80 \\
\hline 2 & 0.89 & 18.59 & 99.97 & 59.70 & 0.00 & 4.69 & 0.36 & 15.36 & 4.02 & 0.38 & 0.65 \\
\hline 3 & 0.75 & 10.23 & 93.40 & 34.64 & 11.47 & 1.38 & 0.13 & 12.25 & 3.42 & 0.38 & 0.57 \\
\hline 4 & 0.79 & 9.35 & 99.81 & 40.89 & 40.14 & 2.64 & 0.28 & 11.00 & 4.60 & 0.91 & 0.87 \\
\hline 5 & 0.64 & 9.50 & 95.28 & 15.88 & 1.81 & 1.01 & 0.11 & 10.77 & 3.79 & 0.37 & 0.71 \\
\hline 6 & 0.87 & 19.81 & 99.88 & 10.75 & 1.67 & 3.36 & 0.41 & 9.59 & 3.39 & 0.60 & 0.74 \\
\hline 11 & 0.67 & 19.84 & 86.21 & 9.78 & 1.93 & 0.89 & 0.09 & 11.29 & 1.93 & 0.47 & 0.54 \\
\hline 12 & 0.71 & 21.37 & 96.04 & 50.32 & 68.65 & 3.03 & 0.33 & 10.69 & 2.80 & 0.84 & 0.74 \\
\hline 14 & 0.79 & 9.50 & 99.98 & 24.49 & 37.58 & 2.84 & 0.32 & 10.31 & 4.13 & 0.90 & 0.72 \\
\hline 16 & 0.81 & 11.32 & 99.98 & 11.91 & 0.19 & 2.00 & 0.23 & 9.94 & 3.70 & 0.58 & 0.78 \\
\hline 17 & 0.82 & 9.67 & 99.93 & 9.46 & 0.70 & 2.01 & 0.24 & 9.73 & 3.80 & 0.57 & 0.85 \\
\hline 18 & 0.70 & 6.64 & 94.11 & 27.19 & 47.71 & 1.82 & 0.24 & 8.79 & 2.94 & 0.40 & 0.53 \\
\hline 19 & 0.74 & 12.22 & 99.04 & 9.88 & 0.00 & 1.88 & 0.19 & 11.25 & 3.94 & 0.77 & 1.20 \\
\hline 20 & 0.74 & 11.78 & 98.88 & 11.08 & 0.00 & 1.40 & 0.17 & 9.88 & 3.61 & 0.70 & 0.94 \\
\hline 22 & 0.76 & 11.22 & 99.87 & 9.29 & 1.24 & 1.58 & 0.18 & 10.45 & 3.94 & 0.63 & 0.75 \\
\hline 23 & 0.63 & 7.80 & 79.79 & 17.30 & 25.40 & 0.94 & 0.12 & 9.25 & 2.25 & 0.25 & 0.37 \\
\hline 24 & 0.54 & 34.89 & 62.14 & 10.96 & 33.42 & 0.51 & 0.05 & 11.35 & 2.01 & 0.31 & 0.42 \\
\hline 25 & 0.63 & 58.09 & 51.54 & 13.26 & 38.61 & 1.26 & 0.14 & 10.51 & 1.34 & 0.21 & 0.27 \\
\hline 26 & 0.62 & 70.89 & 45.97 & 28.97 & 29.05 & 0.82 & 0.09 & 10.86 & 1.38 & 0.22 & 0.52 \\
\hline 28 & 0.77 & 9.95 & 99.99 & 41.87 & 44.44 & 3.21 & 0.33 & 11.37 & 3.82 & 1.75 & 0.59 \\
\hline 29 & 0.67 & 10.62 & 92.01 & 31.28 & 22.93 & 0.87 & 0.11 & 9.39 & 2.96 & 0.34 & 0.37 \\
\hline 30 & 0.54 & 57.99 & 54.44 & 10.20 & 0.94 & 0.33 & 0.04 & 8.80 & 1.89 & 0.32 & 0.61 \\
\hline 31 & 0.83 & 10.01 & 99.86 & 9.95 & 0.01 & 2.51 & 0.31 & 9.45 & 4.08 & 0.69 & 0.91 \\
\hline
\end{tabular}


cultrifera were given zero weight since they were only found in high densities at Stns 13 and 15 and were absent at all other stations. All data were log-transformed and sample scores were scaled as weighed mean species scores. The axes of the CA were related to site-specific environmental variables as summarized through the first 3 axes of the PCA, water depth and $\mathrm{O}_{2}$ flux into the sediment by means of indirect gradient analysis (Jongman et al. 1987). For Stns 7, 8, 9, 10, 13 15, 32 and 33, no solid-phase data were available and at Stn 31, no oxygen flux was measured.

All contour plots were computer generated using kriging gridding algorithm. The contour maps were restricted between the 0 and $200 \mathrm{~m}$ isobaths, west of $32^{\circ}$ longitude, south of Stn 6 and north of Stn 30 . If data for Stns 2 and 5 were present, the value was visualized in a small rectangle.

\section{RESULTS}

\section{Abiotic sediment characteristics}

Table 2 summarizes the results of the sediment analysis. Since we were interested in spatial distribution rather than depth profiles, each variable was inte- grated over the first $21 \mathrm{~cm}$ in the sediment, the zone in which most early diagenetic processes take place. The same analysis over the depth ranges $0-1$ and $0-5 \mathrm{~cm}$ gave comparable results. Median grain sizes on the continental shelf varied between $6.6 \mu \mathrm{m}$ at Stn 18 and $70.9 \mu \mathrm{m}$ at $\operatorname{Stn} 26$. The average grain size was $19.9 \mu \mathrm{m}$. Very fine-grained sediments, with a silt fraction $(<64 \mu \mathrm{m})$ of more than $90 \%$, were observed seaward of the Danube Delta and in the northern part of the continental shelf (Fig. 2A). The sediment became codrser grained south of the Danube Delta (Stns 24, 25 and 26) with median grain sizes of 35,58 and $71 \mu \mathrm{m}$, respectively, probably as a result of higher current velocities in this area. Generally, the total carbonate content of the sediment increased with water depth (Fig. 2B), with lowest concentrations in front of the river mouths. Highest concentrations were found at the bivalve dominated, central part of the continental shelf, with carbonate concentrations up to $84 \%$ of the sediment dry weight. In general, the concentration of iron (Fig. 2C) was negatively related to the median grain size. Especially at the coarse-grained Stns 24, 25 and 26 the measured iron concentrations were low. Iron concentration in front of the Danube Delta was higher than in front of the rivers Dnieper and Dniester. The $\mathrm{C} / \mathrm{N}$ ratio is low in the Danube prodelta and in the southern part
Fig. 2. Spatial distribution of (A) median grain size $(\mu \mathrm{m})$, (B) total carbonate content (\%), (C) iron content on a carbonate-free basis (\%, see 'Material and methods') and (D) molar $\mathrm{C} / \mathrm{N}$ ratio (-) on the continental shelf. Only the stations for which specific data were available are indicated

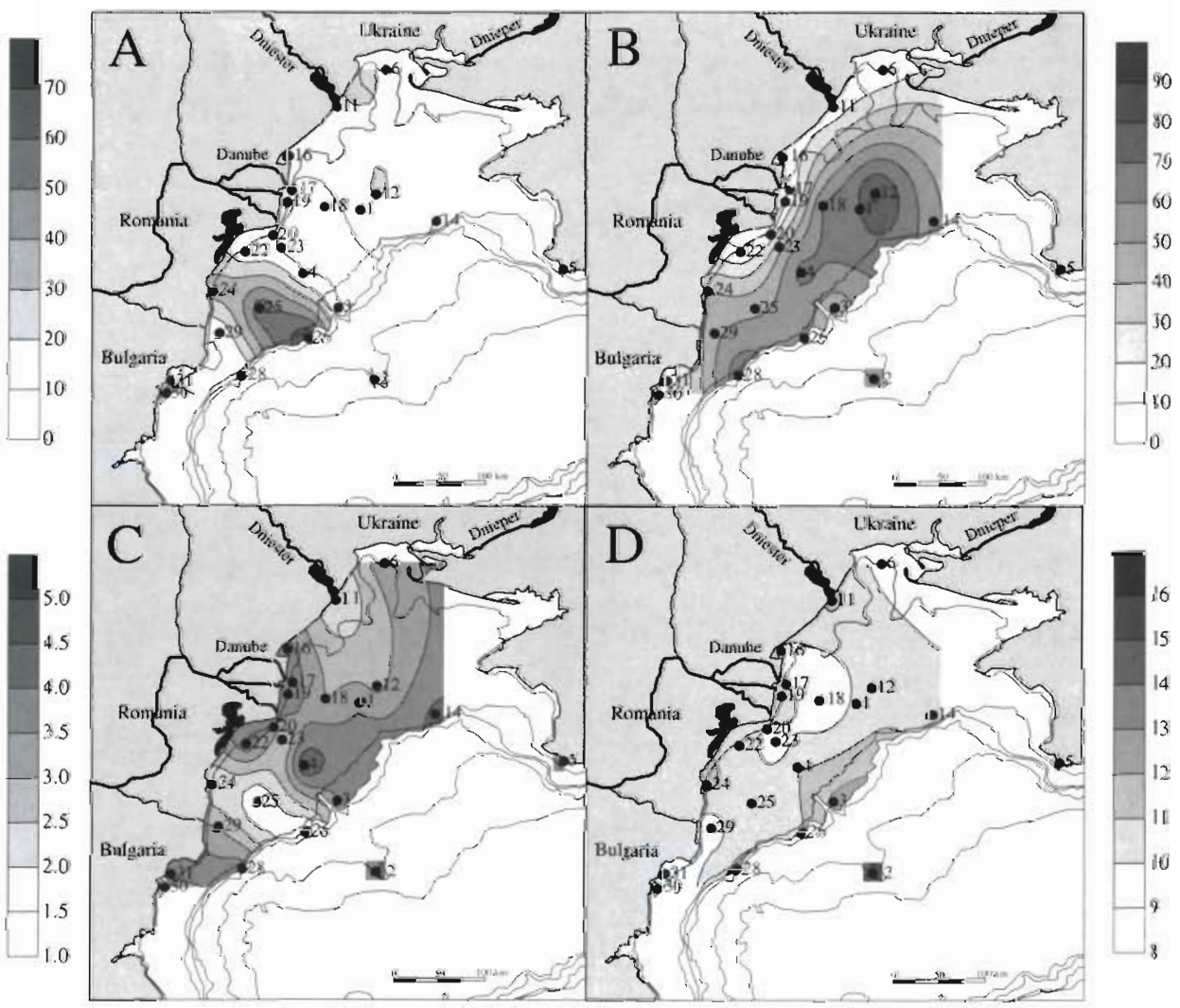




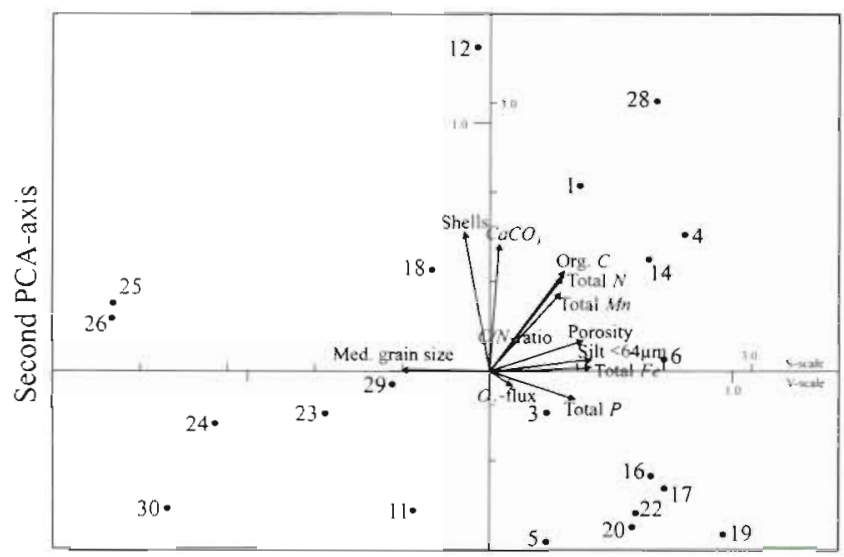

First PCA-axis

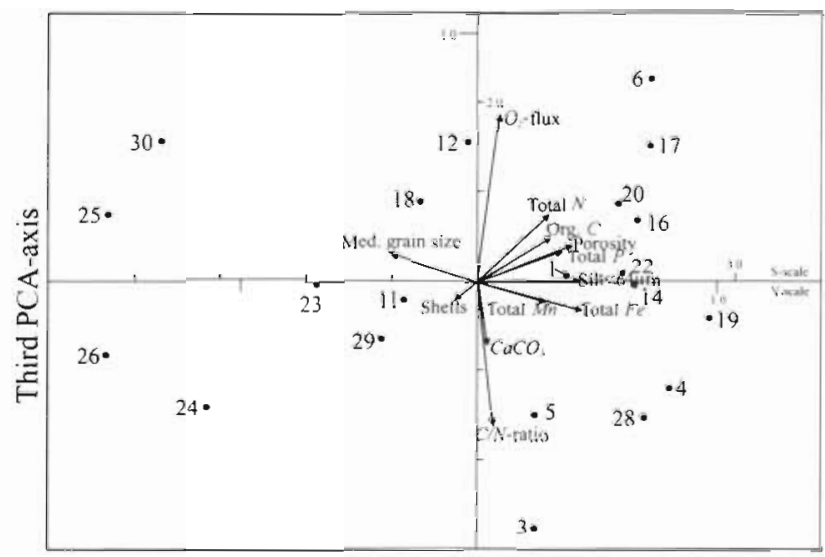

First PCA-axis

Fig. 3. Euclidean distance bi-plots of the sampling stations $(\bullet)$ and the abiotic sediment characteristics $(\longrightarrow)$ along the first 3 principal components. Note the different scale for sampling sites (S-scale) and variables (V-scale)

of the continental shelf (Stns 29, 30 and 31; Fig. 2D). The station in front of the River Dniester had a higher $\mathrm{C} / \mathrm{N}$ ratio than the stations in front of the rivers Danube and Dnieper. In general, the $\mathrm{C} / \mathrm{N}$ ratio increased with water depth, with the highest $\mathrm{C} / \mathrm{N}$ ratio at Stn 2 located in the abyssal part of the Black Sea.

The first 3 principal components explained 43.5, 22.5 and $13.3 \%$ respectively of the total variance in the data (Fig. 3). The first principal component $\left(\lambda_{1}=5.22\right)$ was mainly related to sediment texture. Median grain size was, as expected, inversely related with porosity and silt fraction. Coarse-grained sediments were generally poor in total iron, manganese and phosphorus. This is probably related to the decreasing number of potential binding sites with increasing grain size. The second principal component $\left(\lambda_{2}=2.70\right)$ was associated with carbonate parameters (shells and $\mathrm{CaCO}_{3}$ ) and the third principal component $\left(\lambda_{3}=1.59\right)$ was positively related to the oxygen flux to the sediment and negatively related to the $\mathrm{C} / \mathrm{N}$ ratio. This confirms the notion that low $\mathrm{C} / \mathrm{N}$ ratios indicate more labile organic matter and may therefore lead to higher rates of mineralization and higher oxygen fluxes.

The first principal component clearly separated the stations located on the southern part of the continental shelf (Stns 23, 24, 25, 26, 29 and 30) from the other stations. These coarse-grained sediments were relatively low in organic carbon and total nitrogen. Low carbonate contents were observed at the fine-grained sediments in front of the Danube Delta (Stns 16, 17, 19, 20 and 22). Highest carbonate contents were observed at bivalve-dominated stations on the central continental shelf (Stns 1, 4, 12,14 and 18) and at Stn 28, located at the oxic-anoxic interface. The stations in front of the rivers Dniester and Dnieper (Stns 11 and 6, respectively) showed no clear similarity with the stations in front of the Danube Delta. They were slightly coarser grained and Stn 6 had a higher organic carbon concentration $(3.4 \%)$ than the stations in front of the Danube Delta. Stn 11, in front of the Dniester River, had a low concentration of total iron compared to the stations in front of the Danube Delta. The 3 stations located near the oxic-anoxic interface (Stns 3,26 and 28) showed no similarity in their biogeochemical characteristics.

\section{Sediment community oxygen consumption}

The average SCOC was 21.4 (SD 13.4) $\mathrm{mmol} \mathrm{O}_{2} \mathrm{~m}^{-2}$ $\mathrm{d}^{-1}$. The difference between duplicate measurements averaged $24 \%$ of the mean. The spatial distribution on the continental shelf is shown in Fig. 4. Highest rates were measured at the coastal stations and at Stn 12 on the continental shelf. Despite the absence of data in the relatively large area between Stns 6, 11 and 12, the algorithm interpolates between those stations. The average flux at the stations in the vicinity of the 3 major rivers (Stns 6, 11, 16, 17, 19, 20, and 22) was 32.1 (SD 5.6) $\mathrm{mmol} \mathrm{O}_{2} \mathrm{~m}^{-2} \mathrm{~d}^{-1}$, which was significantly higher ( $t$-test, $p<0.01)$ than the average flux at the other stations (16.1 [SD 13.0] $\mathrm{mmol} \mathrm{O}_{2} \mathrm{~m}^{-2} \mathrm{~d}^{-1}$ ). The high flux at Stn 30 may have been caused by the influence of the harbor of Varna. The highest oxygen flux was recorded at $\operatorname{Stn} 12\left(51.6 \mathrm{mmol} \mathrm{O} \mathrm{m}^{-2} \mathrm{~d}^{-1}\right)$. This station was dominated by the bivalves Modiolus phaseolinus and Mytilus galloprovincialis with a total biomass of $13 \mathrm{~g} \mathrm{AFDW} \mathrm{m}^{-2}$. Lowest fluxes were measured at stations with low oxygen concentrations in the near bottom water, located at the oxic-anoxic interface (Stns 3, 26 and 28). Macrobenthos biomass was extremely low at these stations ( 0 to $0.01 \mathrm{~g} \mathrm{AFDW} \mathrm{m}^{-2}$ ). 


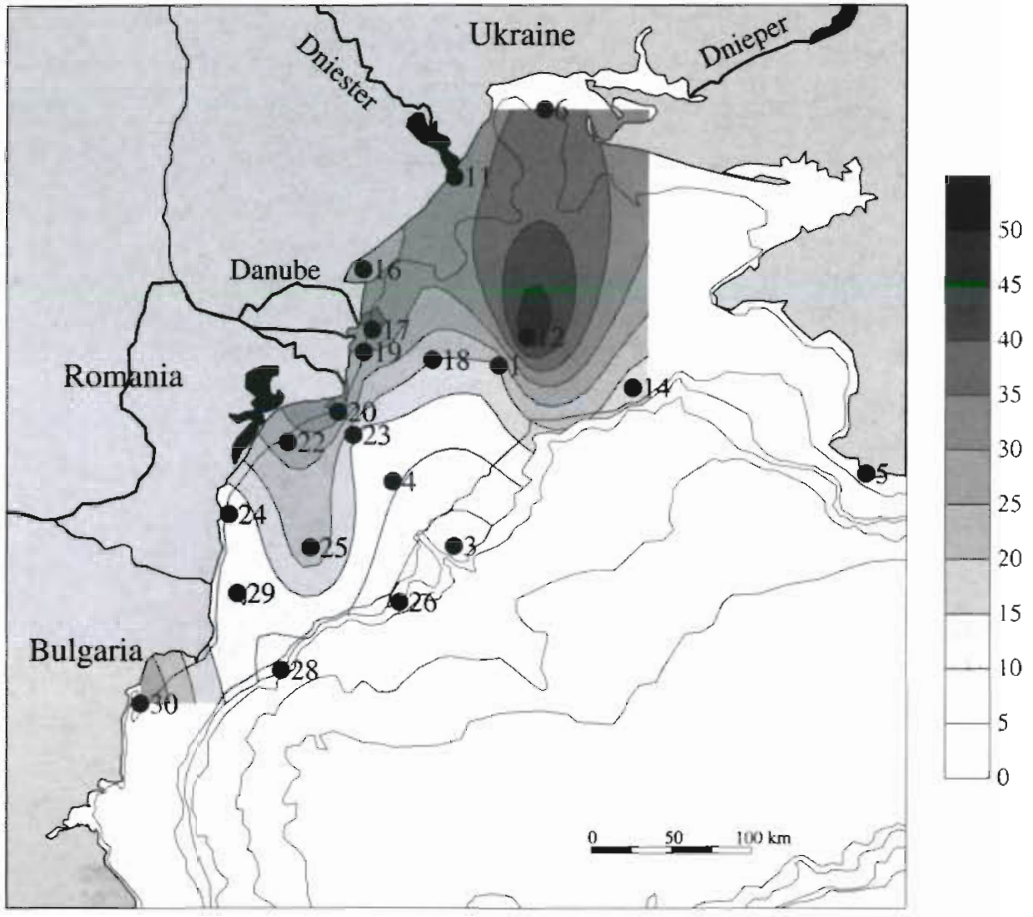

Fig. 4. Spatial distribution of sediment community oxygen consumption (SCOC) (mmol $\mathrm{O}_{2} \mathrm{~m}^{-2} \mathrm{~d}^{-1}$ ) on the continental shelf measured using deck incubation. ( Stations where SCOC was measured

were most widely spread and found at 16 of the 30 stations on the continental shelf. The total macrobenthos biomass ranged from $0 \mathrm{~g} A F D W \mathrm{~m}^{-2}$ at Stns 3 and 26 to $31.9 \mathrm{~g} \mathrm{AFDW} \mathrm{m}^{-2}$ at Stn 29 , which was dominated by the bivalve Mytilus galloprovincialis. On average, the macrobenthos biomass was 11.8 (SD 9.8) $\mathrm{g}$ AFDW $\mathrm{m}^{-2}$. The average total density was 2520 (SD 3320) ind. $\mathrm{m}^{-2}$ Highest densities were found at Stn 19 in front of the Danube Delta with 18000 ind. $\mathrm{m}^{-2}$. At the stations on the continental margin, the macrobenthos density was low (Stn 28) or zero (Stns 3 and 26). At Stn 28, only the polychaete Heteromastus filiformis (79 ind. $\mathrm{m}^{-2}$ ) and the cnidarian Pachycerianthus imperator (158 ind. $\mathrm{m}^{-2}$ ) were found. Species heterogeneity expressed as $N_{1}$ was highest at $\operatorname{Sin} 5\left(N_{1}=16.6\right)$. Lowest diversity was recorded at Stns 8 and $28\left(N_{1}=1.24\right.$ and 1.89 respectively). $N_{1}$ correlated strongly with $N_{2}(\mathrm{r}=0.97)$ but less with $N_{0}(\mathrm{r}=0.81)$ and $N_{\infty}(\mathrm{r}=0.84)$.

The first 3 axes of the correspondence analysis explained $31.5 \%$ of the total variation in the species data (Fig. 6).

\section{Macrobenthos}

A total of 73 macrobenthos species $(>1 \mathrm{~mm})$ were identified. Dominant species were defined as species that account for more than $10 \%$ of the total AFDW at, at least, 1 station on the continental shelf. A total of 18 dominant species were distinguished (Fig. 5). The polychaetes Polydora ciliata and Melinna palmata The first axis $\left(\lambda_{1}=0.60\right)$ was mainly related to water depth. The shallow coastal stations were dominated by the Nereidae species (Nereis diversicolor, $N$. rava, $N$. succinea and $N$. zonata) while the bivalve Modiolus phaseolinus and the polychaete Terebellides stroemi dominated the deeper stations. The second axis $\left(\lambda_{2}=0.44\right)$ was indicative for Stn 30 (characterized by the gastropod Nassa reticulata) and Stn 5
Fig. 5. Distribution of the dominant macrobenthic species on the continental shelf. The biomass ( $g$ ash-free dry weight [AFDW] $\mathrm{m}^{-2}$ ) is classified into 4 size groups as indicated by the size of the marker. Dominant species were defined as species that account for more than $10 \%$ of the total macrobenthos biomass (g AFDW m ${ }^{-2}$ ) at, at least, 1 station. Both stations and species were ordered according to their location on the first CA-axis

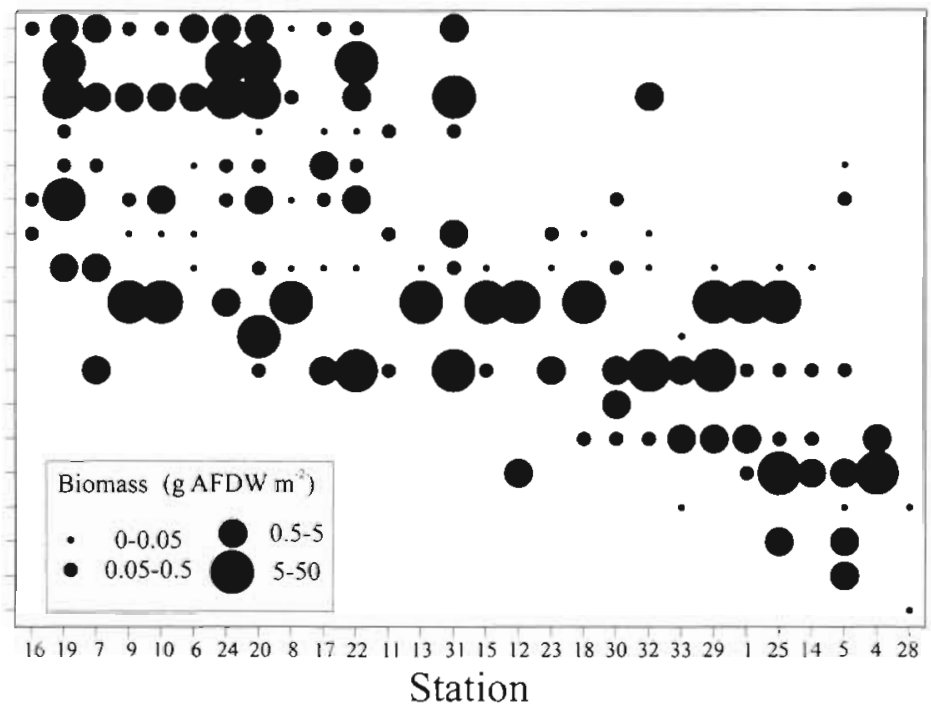



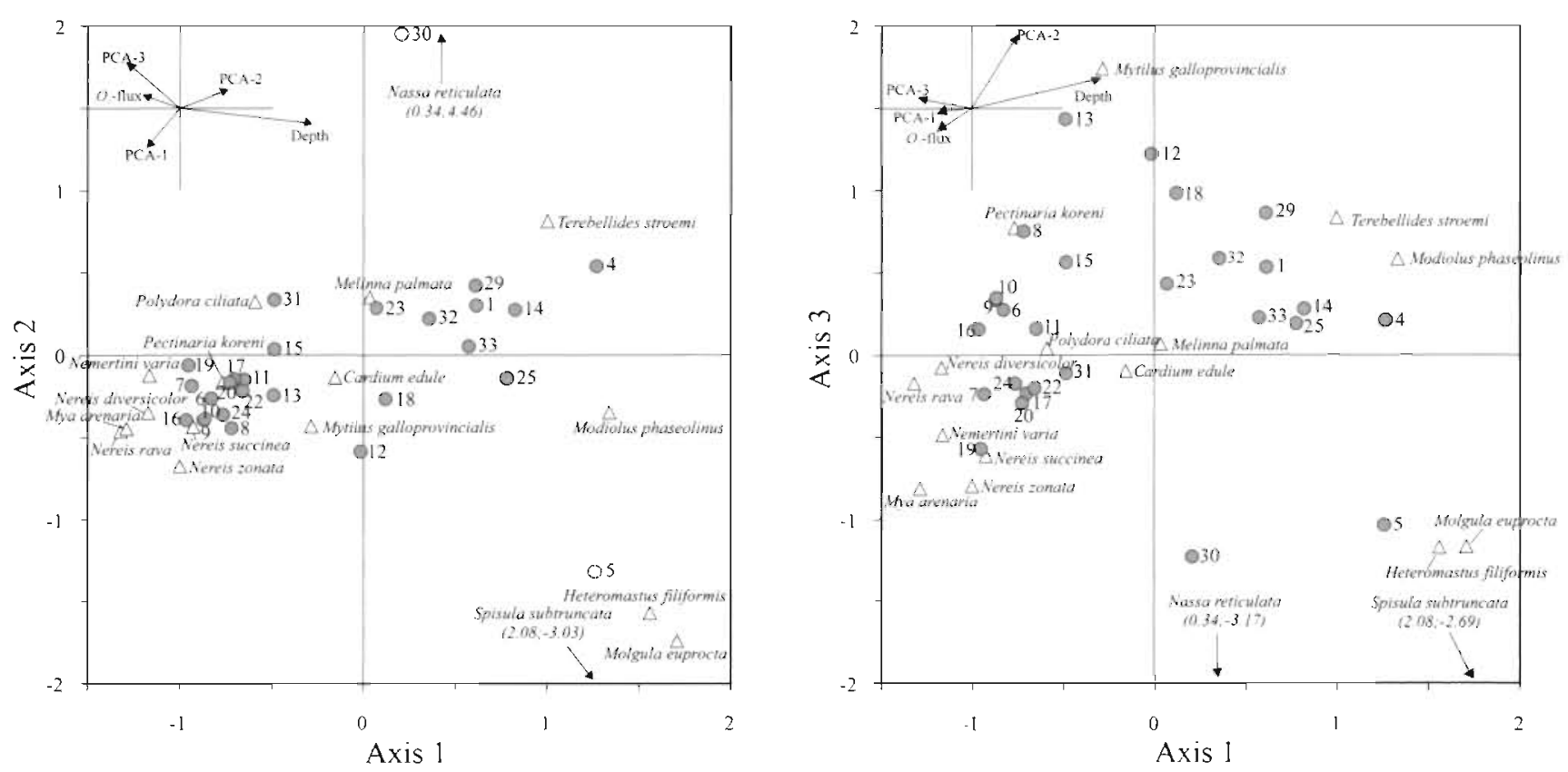

Fig. 6. Correspondence Analysis (CA) ordination diagrams of the macrobenthos data on the first 3 CA-axes. (0) Site scores,

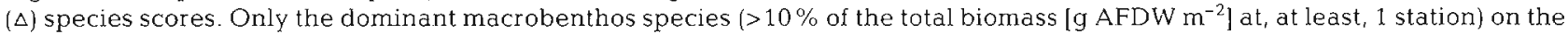
continental shelf are plotted. The insets in the upper left corners show the vectors of some environmental variables. PCA-1, PCA2 and PCA-3: first 3 axes of the PCA (Principal Components Analysis), Depth: water depth and $\mathrm{O}_{2}$-flux: oxygen flux into the sediment. Stn 28 was excluded from the CA-ordination (see 'Material and methods')

(characterized by the bivalve Spisula subtruncata). The higher value of Stn 31 on the second axis compared to the other shallow water stations might be related to a different macrobenthos composition due to its southern geographical position. The third axis $\left(\lambda_{3}=0.39\right)$ separated the stations on the northern part of the continental shelf (Stns 8, 9,10,13 and 15) from the stations in front of the river mouths. This division was mainly based on the absence of the bivalve Mytilus galloprovincialis at the stations in front of the major rivers that were characterized by fine-grained sediments (indicated by a high value of PCA-1). Although no abiotic data for the stations from cluster I (Stns 8, 9, 10,13 and 15) were available, the relation with PCA-1 suggests that the sediments at these stations were relatively fine grained. The low carbonate content at the stations in front of the major rivers is reflected in the low value of the second principal component (PCA-2), which was mainly related to the third CA-axis.

\section{DISCUSSION}

\section{Impact of the River Danube}

Dissolved and particulate material input through large rivers has a substantial influence on both the qualitative and quantitative sedimentary regime in adjacent continental shelf systems. Rhoads et al. (1985) have developed a general model for sedimentary shelf processes related to discharges of effluents of larger rivers (Fig. 7). In general, they distinguished 3 areas: the delta area, the plume area and the shelf area outside the river influence. In the delta area the primary production is light limited due to high concentrations of suspended solids discharged through the river. Sediment deposition rates are generally high and, as a result, the labile algal material deposited on the seabed is diluted by large amounts of terrigenous material (Aller \& Aller 1986). In the eutrophic plume area primary production increases due to increased visibility. Labile marine bioseston becomes a more important component of the organic matter flux to the benthos and can support a high standing stock of benthic populations. In the oligotrophic outer shelf region the primary production is nutrient limited. The carbon flux to the sediment is very low and therefore the benthic standing stock is reduced in this area (Rhoads et al. 1985, Rowe et al. 1991). The dimensions and locations of these different areas depend on both the river properties (amount of freshwater discharge, the concentration and composition of the nutrients and the amount and type of suspended solids) and the properties of the adjacent continental shelf (hydrodynamics, morphology). 
Fig. 7. Generalized model for influence of the discharge of a large river on the sedimentation processes on the shelf. Arrows indicate nutrient transport and sedimentation. Adapted from Rhoads et al. (1985)

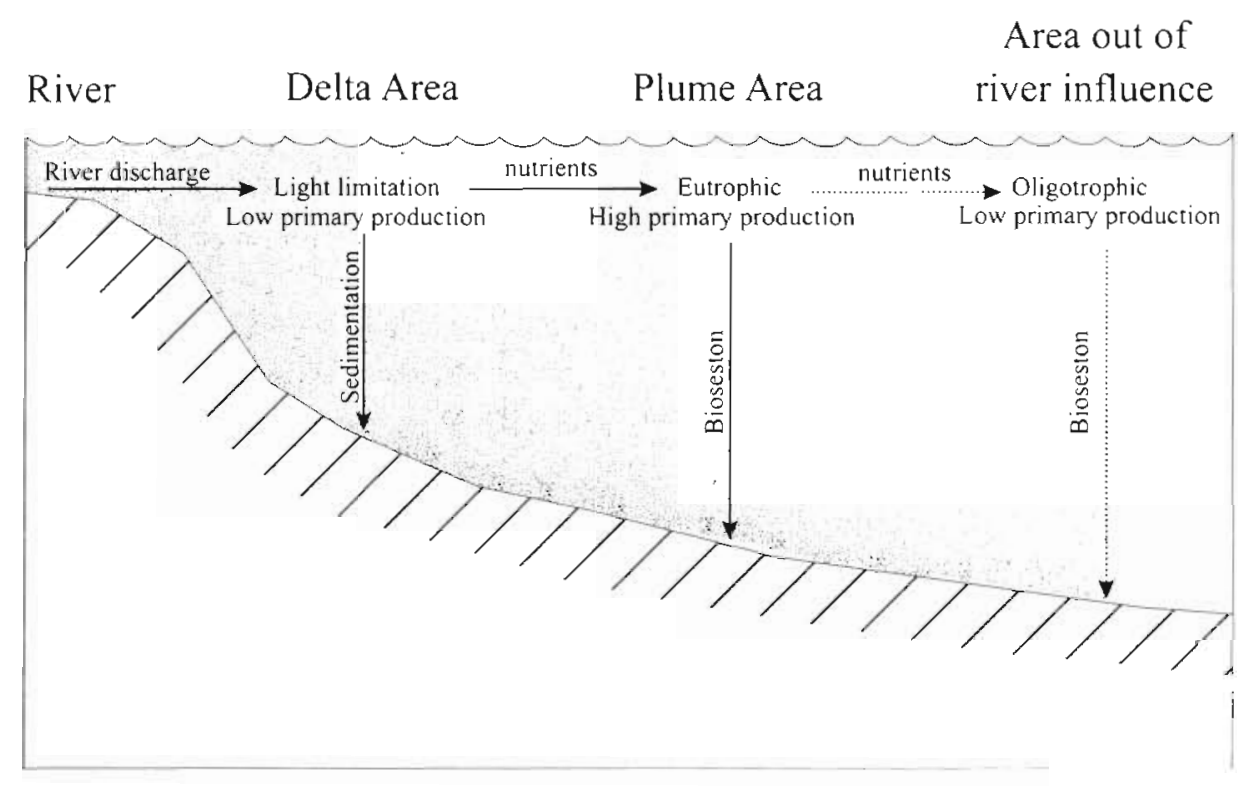

In this paper we have attempted to identify the different sedimentological regions on the continental shelf in relation to the River Danube, which is by far the most important river on the continental shelf in terms of freshwater, suspended solids and nutrient discharge into the Black Sea (Popa 1993). Referring to the general current pattern on the continental shelf, we can indicate the 3 different areas. The stations located just in front of the River Danube (Stns 16, 17, 19, 20 and 22) are directly influenced by the Danube discharges and can be identified as the 'Delta' stations. The water is turbid in this area (Krustalev et al. 1990) with relatively high rates of sedimentation. From ${ }^{137} \mathrm{Cs}$ data at a station just in front of the Danube Delta (Curtis \& Broadway 1992) the sedimentation has been estimated at $0.7 \mathrm{~cm} \mathrm{yr}^{-1}$. From here, the majority of the Danube water is transported north to the anticyclonic gyre (M. L. Grégoire \& J. M. Beckers pers. comm., based on results of a high-resolution hydrodynamic model). Though the exact location of this gyre is dependent on wind patterns, it is very robust and generally located northwest of the mouth of the Danube (Stns 1, 8, 12, 13, 15 and 18). During the transportation, which takes about $2 \mathrm{wk}$, the concentration of suspended solids in the water column decreases (Krustalev et al. 1990), resulting in a higher light-penetration depth. It can be expected that this will lead to a higher primary production in this area, and, therefore, this area can be characterized as the 'eutrophic' area. From the gyre, the water is transported southward over the continental shelf along the Romanian shore towards Bulgaria. The decreased nutrient concentrations in the water column will reduce the primary production and, therefore, this area can be characterized as the 'oligotrophic' area.
The PCA showed that sediments in the Danube Delta area were very fine grained with median grain sizes ranging from 9.7 to $12.2 \mu \mathrm{m}$. Since high amounts of organic matter are generally transported by rivers (Ittekkot \& Laane 1991), the carbon flux to the sediment is expected to be high in this area. This is also reflected in the relatively high SCOC recorded in this area. The source of the organic matter transported by the Danube can be either allochthonous (terrestrial) or the generally more labile autochthonous material such as river phytoplankton (Mook \& Tan 1991). The C/N ratio of fresh terrestrial organic matter is typically higher than organic matter derived from phytoplankton (respectively $>12$ and 6 to 9) (Thornton \& MCManus 1994). During the process of aging, the $\mathrm{C} / \mathrm{N}$ ratio of terrestrial-based detritus will decrease while the $\mathrm{C} / \mathrm{N}$ ratio of algal-based detritus will increase (Rice \& Tenore 1981, Jørgensen 1983). The $\mathrm{C} / \mathrm{N}$ ratio can be used as a measure for the 'quality' of the organic matter to the benthos (Burdige 1991), but one should be aware of this source effect (Cowie \& Hedges 1994). The relatively low $\mathrm{C} / \mathrm{N}$ ratios in the Danube Delta area were an indication that the organic matter was mainly algal-based detritus. Probably the terrestrially derived material, transported by the river, was trapped in the inner-delta. The slight decrease in $\mathrm{C} / \mathrm{N}$ ratio towards Stns 16, 17, 18 and 23 indicated that the deposited organic matter became more labile at these stations.

Going to the anticyclonic gyre in the northern part of the continental shelf (i.e the 'eutrophic' area), the sedimentation rate decreases. However, the oxygen fluxes recorded in this area remained relatively high. At Stn 12, which was dominated by the filter-feeding bivalve Mytilus galloprovincialis, the highest SCOC was measured (52 $\left.\mathrm{mmol} \mathrm{O}_{2} \mathrm{~m}^{-2} \mathrm{~d}^{-1}\right)$. This is an indication of a 
high flux of labile organic carbon to the sediment in this area. All the stations in this area were high in carbonate content and dominated by $M$. galloprovincialis.

In the southern part of the continental shelf (i.e. the 'oligotrophic' area) the influence of the River Danube is reduced. The sediment became coarser grained and oxygen flux to the sediment decreased, indicating a low flux of labile detritus to the sediment.

The effect of the River Danube was also reflected in the macrobenthos distribution. The low carbonate concentrations recorded in the delta area already suggested that this region was less dominated by bivalves compared to the offshore area. The polychaetes Nereis diversicolor, $N$. rava and $N$. succinea and the bivalve Mya arenaria, characteristic for the delta area, are adapted to the high rates of sedimentation and corresponding factors such as sediment stability, food supply and larval supply (Snelgrove \& Butman 1994). The macrobenthos community of the northern part of the continental shelf, where the anticyclonic gyre is located, was characterized by a high biomass of Mytilus galloprovincialis. This confirms the suggestion of a relatively high deposition rate of labile organic matter in this 'eutrophic' area.

\section{Sedimentation and trophic structure}

Abiotic environmental characteristics (hydrology and sediment composition) and population dynamics (competition, mortality/predation and reproduction) are the major factors determining the macrobenthos composition in the sediment (Gaston \& Nasci 1988, Rosenberg 1995). In this study we were mainly interested in the effects of sedimentation on the macrobenthos community composition. Since feeding type of the macrobenthos community is an adaptation to the sedimentological environment, it can be expected that differences in sedimentation will be reflected in the distribution of the different trophic groups on the shelf.

Macrobenthos was classified into 6 different feeding groups according to Fauchald \& Jumars (1979). The biomass of interface feeders and deep deposit feeders was, in general, less than $3 \%$ of the total macrobenthos population, except for Stn 7. where interface feeders accounted for $21 \%$ of the total biomass. Therefore, interface feeders and deep deposit feeders were grouped together with surface deposit feeders. In Fig. 8 the relative contribution of the different trophic groups to the total macrobenthos bio-

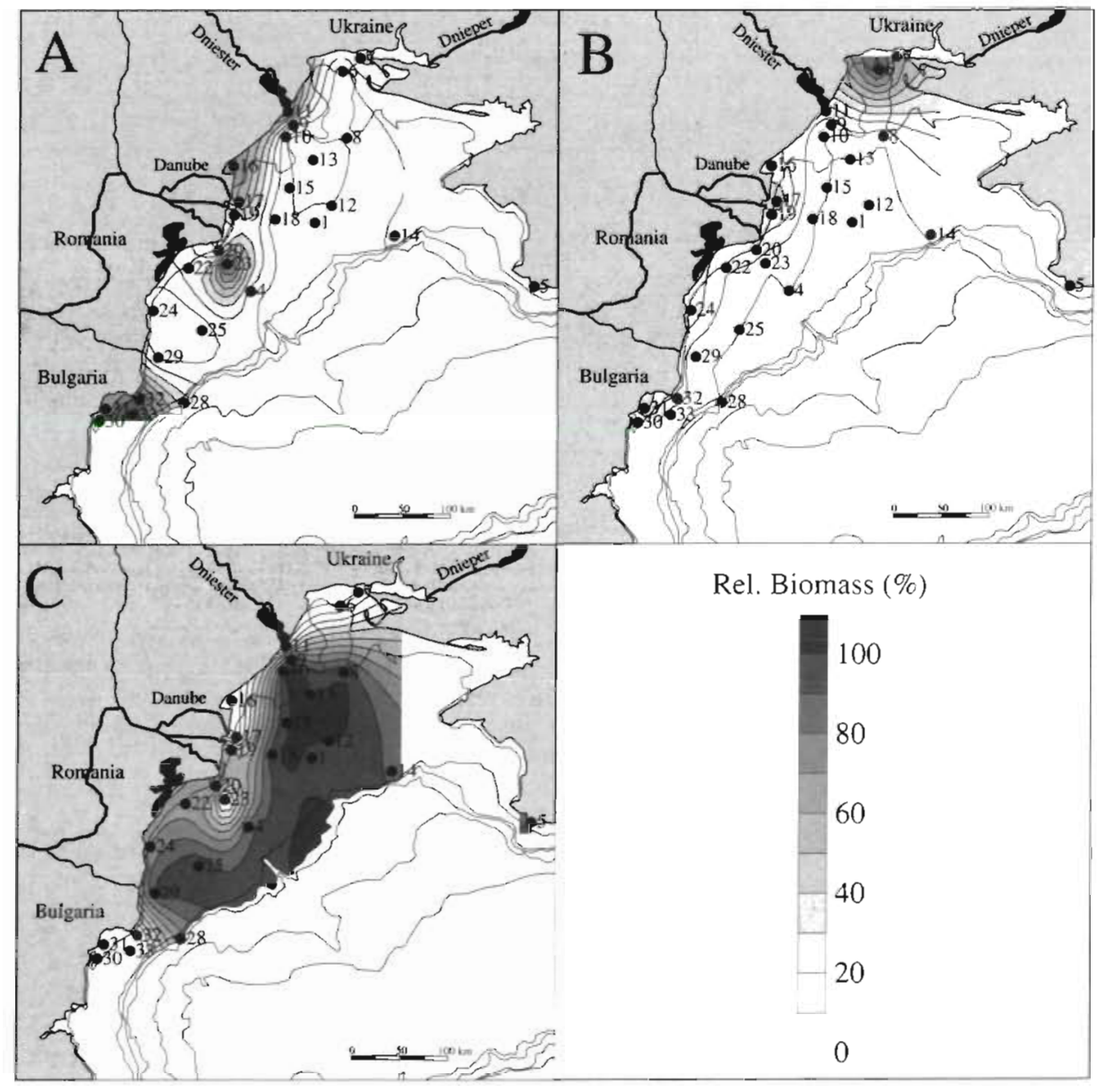

Fig. 8. Relative contribution $(\%)$ to the total macrobenthos biomass in the continental shelf of (A) the sum of interface, surface and deep deposit feeders, (B) omnivores/predators and (C) suspension feeders 
mass is given. Stns 3, 26 and 28 were neglected in these figures.

Deposit feeders forage on organic matter in the sediment or deposited at the sediment-water interface. The standing stock of bacteria in the sediments is usually too low to supply the total carbon demand of the deposit feeders (Kemp 1987). Therefore, they need an additional (non-living) carbon source. Since deposit feeders subsist on a remarkably poor food source, they depend on high accumulation rates of organic carbon (Pearson \& Rosenberg 1978, Lopez \& Levinton 1987. Weston 1990). Deposit feeders dominated the macrobenthos biomass in the stations located in front of the river mouths (Stns 11, 16, 17 and 19) and in front of the Bulgarian coast (Stns 30 to 33), where the surface deposit feeder Melinna palmata was dominant. Stn 23 , where the total biomass was low $\left(2.3 \mathrm{~g} \mathrm{AFDW} \mathrm{m}^{-2}\right)$, was also dominated by $M$. palmata.

Omnivores and predators are more directed towards their food item, and will, in general, not consume the sediment as a whole as deposit feeders do. This is less energy consuming, but, since they are more selective, the proper food type is, in general, less abundant. Predators and omnivores were, like deposit feeders, abundant at the near-shore stations. This suggests that the carbon flux in this area is high enough to support a substantial density of higher trophic levels. Stns 6 and 7 , located in front of the Dnieper river were dominated by Nereis diversicolor. This polychaete accounted for 83 and $47 \%$, respectively, of the total macrobenthos biomass at these stations.

Suspension feeders retrieve their food directly from the water column. When the food source in the near bottom water is continuously renewed, suspension feeders can locally increase the flux of organic matter to the sediment (Heip et al. 1995). Suspension feeders are often negatively related to the percentage of mud in the sediment (Eleftheriou \& Basford 1989, Aller \& Stupakoff 1996). Depending on morphology, the filtering apparatus may be vulnerable to clogging at high concentrations of suspended solids in the near bottom water. The lack of suspension feeders in front of the river mouths may be caused by high concentrations of suspended solids in this area. Both in the northern part (Stns 1, 8, 9, 10,13,14, 15 and 18) and in the southern part of the continental shelf (Stns 4, 22, 24, 25 and 29), suspension feeders replace the deposit feeders. At low carbon fluxes it is expected that suspension feeders dominate since they have first access to the sedimenting organic matter (Pearson \& Rosenberg 1978, Weston 1990). This might be the case in the southern part of the continental shelf and at the oxic-anoxic interface, but the high SCOC recorded at Stns 1, 12, 18 and 25, however, do not support this idea for the northern part of the continental shelf. The sediments in this sediment starvation zone consisted of 39 to $69 \%$ of shell remains. Apparently deposit feeders in this area have no access to the organic matter between the shell remains.

\section{Macrobenthos oxygen consumption}

Only part of the oxygen flux into the sediment is consumed through respiration of macrobenthos. The rest is used by micro-and meiobenthos, microorganisms and chemical re-oxidation of reduced substances. In estuaries the macrobenthos can account for up to $90 \%$ of the total SCOC (Heip et al. 1995). Typical values for the part of the SCOC consumed by the macrobenthos reported by various authors are $23 \%$ in the northwestern Barents Sea (Piepenburg et al. 1995), $38 \%$ in the northwestern Adriatic Sea (Moodley et al. 1998) and 16 to $50 \%$ in the Goban Spur area with the lowest values in the lower slope and the abyss (Heip et al. in press).

We used data on individual body mass to assess the oxygen demand of the macrobenthos. Species-dependent allometric relations $\left(R=a W^{b}\right)$ are often used to calculate individual respiration rate $(R)$ from the body mass ( $W$ ) (Banse 1982, Bayne \& Newell 1983). It is impossible to retrieve from literature these relations for all Black Sea species. Even if we were able to find these relations for all species, application of the relations in calculating the total respiration rate of the macrobenthos would not be straightforward. For a wellknown species, such as the blue mussel (Mytilus edulis) for example, the reported estimations of the parameters $a$ and $b$ range from 0.164 to 0.698 and 0.595 to 0.930 respectively, depending on factors such as temperature, feeding, activity, oxygen tension and salinity (Bayne et al. 1976). In this study we used the relation of Mahaut et al. (1995) based on a compilation of shallow water organisms, ranging from bacteria and nematodes to fish.

$$
R=0.0174 \cdot W^{-0.156}
$$

where $R=$ weight-specific respiration rate $\left(\mathrm{d}^{-1}\right)$ and $W=$ individual weight ( $\mathrm{mg} \mathrm{C}$ ). Carbon biomass was estimated assuming that $50 \%$ of the AFDW was organic carbon. Respiration rates were converted to oxygen consumption (mmol $\mathrm{O}_{2} \mathrm{~m}^{-2} \mathrm{~d}^{-1}$ ) assuming a respiratory coefficient of 0.85 (Hargrave 1973) and corrected for temperature assuming a $Q_{10}$ value of 2 (Wells 1980, Piepenburg et al. 1995).

It is obvious that a number of uncertainties are involved in the calculation of macrobenthos respiration. Beside errors in sampling and determination of the macrobenthos, there are many assumptions made for the calculation of the respiration rates of the macrobenthos. Conversion factors to AFDW are based on species from the Baltic Sea (Rumohr et al. 1987). The 


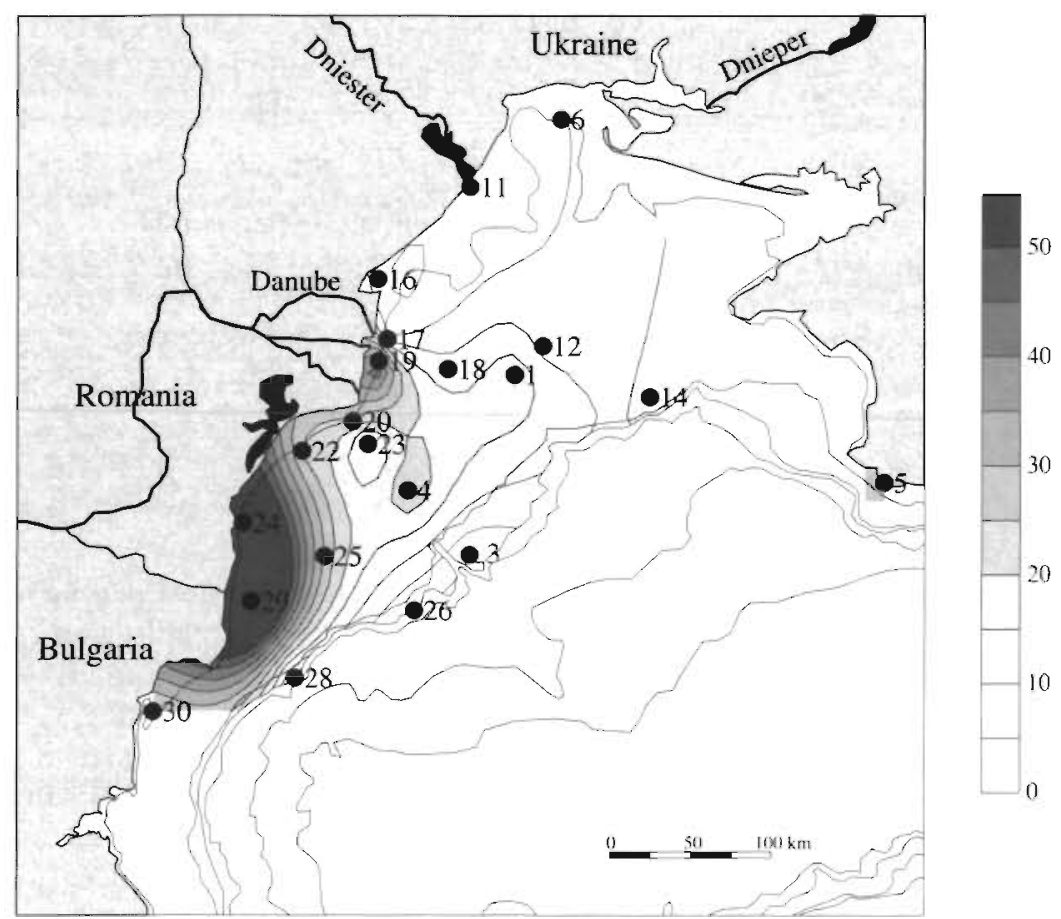

Fig. 9. Spatial distribution of the fraction of the total SCOC (\%) consumed by the macrobenthos on the continental shelf

expected that a large part of the oxygen consumption was due to the (microorganism mediated) re-oxidation of reduced substances in the sediments (Wijsman et al. in press).

South of the Danube Delta the contribution of macrobenthos to the total oxygen consumption increased. At Stns 24 and 29 most of the SCOC was used by the macrobenthos $(75$ and $89 \%$, respectively). Stn 24 was characterized by a high biomass (14 $\mathrm{g} \mathrm{AFDW} \mathrm{m}^{-2}$ ) of large individuals of Nereis diversicolor, which accounted for $53 \%$ of the total oxygen consumption of the macrobenthos. Stn 29 had a high biomass (26 $\mathrm{g}$ AFDW $\mathrm{m}^{-2}$ ) of Mytilus galloprovincialis, accounting for $73 \%$ of the oxygen consumption of the macrobenthos.

The importance of the macrobenthos in the total oxygen consumption decreased towards the oxic-anoxic interface. The stations at the oxic-anoxic interface (Stns 26 and 28) had little or no macrobenthos. Frequently occurring upwellings of anoxic water from the deep sea makes this area a harsh environ-

relation of Mahaut et al. (1995) is a compilation of data from a wide range of different species in different marine shallow water environments.

On average, $21 \%$ of the total oxygen flux to the sediment at the continental shelf of the Black Sea was consumed by macrobenthos (Fig. 9). From the SCOC, it was concluded that the carbon supply to the sediment in front of the major rivers and in the northern part of the continental shelf was high. High mineralization rates result in anoxic conditions in the sediments, which is unfavorable for many macrobenthos species. Therefore, macrobenthos was not important in terms of oxygen consumption in the northern part of the shelf (Stns 6, 11, 12, 16 and 17) and microorganisms, micro- and meiobenthos became more important. At Stns 19, 20 and 22, where high mineralization rates were also recorded, the contribution of macrobenthos to the total SCOC was higher. This was mainly due to the high biomass of Mya arenaria, a bivalve buried deep in the anoxic sediment, that can transport oxygenated water from the water column with its siphons. The lack of burrow-building organisms at the shellrich stations in the northern part of the continental shelf prevented oxygen to be transported into the deeper sediment layers. The contribution of macrobenthos to the total SCOC was low in these bivalvedominated sediments. Since micro- and meiobenthos is also dependent on oxygenated sediments, it can be ment for macrobenthos (Kempe et al. 1990). Microorganisms, and micro- and meiobenthos probably consume most of the oxygen in this area.

For the Goban Spur area (200 to $4500 \mathrm{~m}$ ), Soetaert et al. (1997) and Heip et al. (in press) found that the relative importance of smaller organisms, such as bacteria and protozoa, on the total oxygen consumption increased with decreasing carbon flux. This is probably caused by the low turnover rate of these organisms in the sediment. The relative importance of the macrobenthos in the total carbon respiration also decreased with water depth in this area. The absolute amount of organic carbon supply to the sediment in the deep-sea area may not be sufficient for the larger macrobenthos species to occur. In the Goban Spur area, $(\mathrm{SCOC}=0.3$ to $5.4 \mathrm{mmol} \mathrm{O}_{2} \mathrm{~m}^{-2} \mathrm{~d}^{-1}$ ) (Duineveld et al. $1997 \mathrm{~b}$ ), the carbon flux is limiting the benthic community. In the shallow continental shelf of the Black Sea, where the SCOC ranged from 2 to $52 \mathrm{mmol} \mathrm{O} \mathrm{m}^{-2} \mathrm{~d}^{-1}$, the benthic community is likely to be more inhibited by the oxygen conditions in the sediment resulting from the high carbon input.

\section{CONCLUSIONS}

The influence of the Danube could be traced back in the biotic and abiotic sediment composition of the con- 
tinental shelf of the Black Sea. Fine-grained, carbonate-poor sediments and a high SCOC characterized the delta area. Only a minor part of the oxygen consumption could be attributed to the macrobenthos community, which was dominated by deposit feeders, and predators such as Nereis spp. In the northern part of the continental shelf, where the anticyclonic gyre was located, the rate of sedimentation was lower. However, high oxygen fluxes into the sediment were recorded, indicating a high flux of labile organic matter to the sediment. The macrobenthos community in this area, dominated by suspension feeders such as Mytilus galloprovincialis, was responsible for only a small fraction of the total SCOC. The southern part of the continental shelf can be characterized as the 'oligotrophic' area. Low oxygen fluxes into the sediment were recorded in these coarse-grained sediments. The scarce organic matter arriving at the sediments in this area is efficiently used by the mostly suspension feeding macrobenthos, accounting for a major part of the SCOC.

Acknowledgements. This is a contribution from the EROS2000 (European River and Ocean Systems) and EROS-21 projects to the Environment and Climate Program of the European Communities (EV5V-CT94-0501, ENV4-CT96-0286). Four anonymous reviewers are thanked for constructive comments. We also thank Jack Middelburg and Carlo Heip for comments on earlier versions of the manuscript. The authors wish to thank Sabine Gerbersdorf and Dan Secrieru for their assistance in the field and Peter van Breugel, Yvonne Maas and Joop Nieuwenhuize for the analysis in the lab. Leon Moodley was of great value by testing and optimizing the incubators. Marie-Laure Grégiore and Jean-Marie Beckers are thanked for providing information on the current patterns on the continental shelf that resulted from a high-resolution hydrodynamic model. We also thank the captain and the crew of the RV 'Professor Vodyanitsky' and Prof. Dr Nikolae Panin who was in charge of the expedition. This is contribution no. 090 to the EU program ELOISE and contribution no. 2515 of the Netherlands Institute of Ecology.

\section{LITERATURE CITED}

Aller JY, Aller RC (1986) General characteristics of benthic faunas on Amazon inner continental shelf with comparisan to the shelf off Changjiang River, East China Sea. Cont Shelf Res 6:291-310

Aller JY, Stupakoff I (1996) The distribution and seasonal characteristics of benthic communities on the Amazon shelf as indicators of physical processes. Cont Shelf Res 16:717-751

Banse K (1982) Mass-scaled rates of respiration and intrinsic growth in very small invertebrates. Mar Ecol Prog Ser 9: 281-297

Bayne BL, Newell RC (1983) Physiological energetics of marine molluscs. In: Saleudin ASM (ed) The Mollusca. Academic Press, New York, p 407-515

Bayne BL, Thompson RJ, Widdows J (1976) Physiology: I. In: Bayne BL (ed) Marine mussels their ecology and physio- logy. Cambridge University Press, Cambridge, p 121-159 Bologa AS, Bodeanu N, Petran A, Tiganus V, Zaitsev YP (1995) Major modifications of the Black Sea benthic and planktonic biota in the last three decades. Bull Inst Oceanogr (Monaco) 15:85-110

Burdige DJ (1991) The kinetics of organic matter mineralization in anoxic marine sediments. J Mar Res 49:727-761

Cociasu AM, Dorogan L, Humborg C, Popa L. (1996) Longterm ecological changes in Romanian coastal waters of the Black Sea. Mar Pollut Bull 32:32-38

Cowie GL, Hedges JI (1994) Biochemical indicators of diagenetic alteration in natural organic matter mixtures. Nature 369:304-307

Curtis WR, Broadway JA (1992) Preliminary caesium data from a cooperative US/USSR monitoring survey for Chernobyl radioactivity in the Black Sea. Chem Ecol 7:161-172

Devol AH, Christensen JP (1993) Benthic fluxes and nitrogen cycling in sediments of the continental margin of the eastern North Pacific. J Mar Res 51:345-372

Duineveld GCA, De Wilde PAWJ, Berghuis EM, Kok A Tahey TM, Kromkamp J (1997a) Benthic respiration and standing stock on two contrasting continental margins in the western Indian Ocean: the Yemen-Somali upwelling region and the margin off Kenya. Deep-Sea Res 44 1293-1317

Duineveld GCA, Lavaleye MSS, Berghuis EM, De Wilde PAWJ, Van Der Weele J, Kok A, Batten SD, De Leeuw JW (1997b) Patterns of benthic fauna and benthic respiration on the Celtic continental margin in relation to the distribution of phytodetritus. Int Rev Ges Hydrobiol 82:395-424

Eleftheriou A, Basford DJ (1989) The macrobenthic infauna of the offshore northern North Sea. J Mar Biol Assoc UK 69 : $123-143$

Fabry V, Froehlich K, Osvath I (1993) Environmental pollution of the Black Sea: a search for answers. IAEA Bull 35:20 - 24

Fauchald K, Jumars PA (1979) The diet of worms: a study of polychaete feeding guilds. Oceanogr Mar Biol Annu Rev 17:193-284

Gaston GR, Nasci JC (1988) Trophic structure of macrobenthic communities in the Calcasieu Estuary, Louisiana. Estuaries 11:201-211

Gomoiu MT (1980) Ecological observations on the jellyfish Aurelia auriata (L.) populations from the Black Sea. Cercetari Mar 13:91-102

Gomoiu MT (1985a) Problems concerning marine eutrophication. Cercetari Mar 18:59-95

Gomoiu MT (1985b) On the productive potential of the benthos from the Romanian continental shelf of the Black Sea. Cercetari Mar 18:191-200

Gomoiu MT (1992) Marine eutrophication syndrome in the north-western part of the Black Sea. In: Vollenweider RA (ed) Science of the total environment. Elsevier Sci, Amsterdam, p 683-692

Grégoire M, Beckers JM, Nihoul JCJ, Stanev E (1997) Coupled hydrodynamic ecosystem model of the Black Sea at basin scale. In: Özsoy E, Mikaelyan A (eds) Sensitivity to change: Black Sea, Baltic Sea and North Sea. Kluwer Academic Publishers, Dordrecht, p 487-499

Grégoire M, Beckers JM, Nihoul JCJ, Stanev E (1999) Reconnaissance of the main Black Sea's ecohydrodynamics by means of a 3D interdisciplinary model. J Mar Res 16: 85-105

Hargrave BT (1973) Coupling carbon flow through some pelagic and benthic communities. J Fish Res Board Can 30:1317-1326

Heip CHR, Warwick RM, Carr MR, Herman PMJ, Huys R Smol N, Van Holsbeke K (1988) Analysis of community 
attributes of the benthic meiofauna of Frierfjord/Langesundfjord. Mar Ecol Prog Ser 46:171-180

Heip CHR, Goossen NK, Herman PMJ, Kromkamp J, Middelburg JJ, Soetaert K (1995) Production and consumption of biological particles in temperate tidal estuaries. Oceanogr Mar Biol Annu Rev 33:1-149

Heip CHR, Duineveld GCA, Flach E, Graf G, Helder W, Herman PMJ, Lavaleye MSS, Middelburg JJ, Pfannkuche O, Soetaert K, Soltwedel T, De Stigter HS, Thomsen L. Vanaverbeke J, De Wilde PAWJ (in press) The role of benthic biota in sedimentary metabolism and sedimentwater exchange processes in the Goban Spur area (N.E. Atlantic). Deep-Sea Res

Henrichs SM (1992) Early diagenesis of organic matter in marine sediments: progress and perplexity. Mar Chem 39: $119-149$

Hill MO (1973) Diversity and evenness: a unifying notation and its consequences. Ecology 54:427-432

Humborg C, Ittekkot VA, Cociasu AM, Bodungen BV (1997) Effect of Danube River dam on Black Sea biogeochemistry and ecosystem structure. Nature 386:385-388

Ittekkot VA, Laane RWPM (1991) Fate of riverine particulate organic matter. In: Degens ET, Kempe S, Richey JE (eds) Biogeochemistry of major world rivers. John Wiley \& Sons, Chichester, p 233-243

Jongman RHG, Ter Braak CJF, Van Tongeren OFR (1987) Data analysis in community and landscape ecology. Pudoc, Wageningen

Jørgensen BB (1983) Processes at the sediment-water interface. In: Bolin B (ed) The major biogeochemical cycles and their interactions. John Wiley, New York, p 477-509

Kemp PF (1987) Potential impact on bacteria of grazing by a macrofaunal deposit-feeder, and the fate of bacterial production. Mar Ecol Prog Ser 36:151-161

Kempe S, Liebezeit G, Diercks AR, Asper V (1990) Water balance in the Black Sea. Nature 346:419

Konovalov SM (1995) Anthropogenic impact and ecosystems of the Black Sea. Bull Inst Oceanogr (Monaco) 15:53-83

Krustalev Y, Chernousov SY, Denisov VI (1990) Some distinctive features and laws of sedimentogenesis in the northwestern Black Sea (the material composition and distribution of the suspensions). Oceanology 30:212-216

Leppäkoski E, Mihnea PE (1996) Enclosed seas under maninduced change: a comparison between the Baltic and Black Seas. Ambio 25:380-389

Lopez GR, Levinton JS (1987) Ecology of deposit-feeding animals in marine sediments. Q Rev Biol 62:235-260

Lyons TW, Berner RA, Anderson RF (1993) Evidence for large pre-industrial perturbations of the Black Sea chemocline Nature 365:538-540

Mahaut ML, Sibuet M, Shirayama Y (1995) Weight-dependent respiration rates in deep-sea organisms. Deep-Sea Res 42:1575-1582

Mee LD (1992) The Black Sea in crisis: a need for concerted international action. Ambio 21:278-286

Mihnea PE (1997) Major shifts in the phytoplankton community (1980-1994) in the Romanian Black Sea. Oceanol Acta 20:119-129

Moodley L, Heip CHR, Middelburg JJ (1998) Benthic activity in sediments of the northwestern Adriatic Sea: sediment oxygen consumption, macro- and meiofauna dynamics. J Sea Res 40:263-280

Mook WG, Tan FC (1991) Stable carbon isotopes in rivers and estuaries. In: Degens ET, Kempe S, Richey JE (eds) Biogeochemistry of major world rivers. John Wiley \& Sons, Chichester, p 245-264

Murray JW, Jannasch HW, Honjo S, Anderson RF, Reeburgh
WS, Top Z, Friederich GE, Codispoti LA, Izdar E (1989) Unexpected changes in the oxic/anoxic interface in the Black Sea. Nature 338:411-413

Mutlu E, Bingel F, Gücü AC, Melnikov VV, Niermann U, Ostr NA, Zaika VE (1994) Distribution of the new invader Mnemiopsis sp. and the resident Aurelia aurita and Pleurobrachia pileus populations in the Black Sea in the years 1991-1993. ICES J Mar Sci 51:407-421

Niermann $U$, Bingel $F$, Gorban $A$, Gordina $A D$, Gücü $A C$ Kideys AE, Konsulov A, Radu G, Subbotin AA, Zaika VE (1994) Distribution of anchovy eggs and larvae (Engraulis encrasicolus Cuv.) in the Black Sea in 1991-1992. ICES J Mar Sci 51:395-406

Nieuwenhuize J, Poley-Vos CH, Van Den Akker AH, Van Delft W (1991) Comparison of microwave and conventional extraction techniques for the determination of metals in soil, sediment and sludge samples by atomic spectrometry. Analyst 116:347-351

Nieuwenhuize J, Maas YEM, Middelburg JJ (1994) Rapid analysis of organic carbon and nitrogen in particulate materials. Mar Chem 45:217-224

Oguz T, Malanotte-Rizzoli P (1996) Seasonal variability of wind and thermohaline-driven circulation in the Black Sea: modeling studies. J Geophys Res 101:16551-16569

Pamatmat MM (1971) Oxygen consumption by the seabed. IV. Shipboard and laboratory experiments. Limnol Oceanogr 16:536-550

Parsons TR, Maita Y, Lalli CM (1984) A manual of chemical and biological methods for seawater. Pergamon Press Ltd, Oxford

Pearson TH, Rosenberg R (1978) Macrobenthic succession in relation to organic enrichment and pollution of the marine environment. Oceanogr Mar Biol Annu Rev 16:229-311

Peet RK (1974) The measurement of species diversity. Annu Rev Ecol Syst 5:285-397

Piepenburg D, Blackburn TH, Von Dorrien CF, Gutt J, Hall POJ, Hulth S, Kendall MA, Opalinski KW, Rachor $E_{\text {, }}$ Schmid MK (1995) Partitioning of benthic community respiration in the Arctic (Northwestern Barents Sea). Mar Ecol Prog Ser 118:199-213

Popa A (1993) Liquid and sediment inputs of the Danube river into the north-western Black Sea. Mitt Geol-Palaont Inst Univ Hamburg 74:137-149

Porumb F (1992) On the development of Noctiluca scintillans under eutrophication of Romanian Black Sea waters. In: Vollenweider RA (ed) Science of the total environment. Elsevier Sci Publ, Amsterdam, p 907-920

Rhoads DC, Boesch DK, Zhican T, Fengshan X, Liqiang $H_{\text {, }}$ Nilsen KJ (1985) Macrobenthos and sedimentary facies on the Changjiang delta platform and adjacent continental shelf, East China Sea. Cont Shelf Res 4:189-213

Rice DL, Tenore KR (1981) Dynamics of carbon and nitrogen during the decomposition of detritus derived from estuarine rnacrophytes. Estuar Coast Shelf Sci 13:681-690

Rosenberg R (1995) Benthic marine fauna structured by hydrodynamic processes and food availability. Neth J Sea Res 34:303-317

Rowe G, Sibuet $M$, Deming J, Khripounoff A, Tietjen J, Macko S, Theroux R (1991) 'Total' sediment biomass and preliminary estimates of organic carbon residence time in deep-sea benthos. Mar Ecol Prog Ser 79:99-114

Rumohr H, Brey T, Ankar S (1987) A compilation of biometric conversion factors for benthic invertebrates of the Baltic Sea. Askö Laboratory, Stockholm

Sapozhnikov VV (1992) Biohydrochemical causes of the changes of Black Sea ecosystem and its present condition. Geo Journal 27:149-157 
Snelgrove PVR, Butman CA (1994) Animal-sediment relationships revisited: cause versus effect. Oceanogr Mar Biol Annu Rev 32:111-177

Soetaert K, Heip CHR, Vincx M (1991) Diversity of nematode assemblages along a Mediterranean deep-sea transect Mar Ecol Prog Ser 75:275-282

Soetaert K, Vanaverbeke J, Heip CHR, Herman PMJ, Middelburg JJ, Sandee AJJ, Duineveld GCA (1997) Nematode distribution in ocean margin sediments of the Goban Spur (northeast Atlantic) in relation to sediment geochemistry. Deep-Sea Res 44:9-10

Sorokin Yl (1983) The Black Sea. In: Ketchum BH (ed) Estuaries and enclosed seas. Elsevier, New York, p 253-292

Ter Braak CJF (1988) CANOCO-a FORTRAN program for canonical community ordination by (partial) (detrended) (canonical) correspondence analysis, principal components analysis and redundancy analysis (version 2.1). Agricultural Mathematics Group. Wageningen

Ter Braak CJF (1990) Update notes: CANOCO version 3.10. Agricultural Mathematics Group, Wageningen

Thornton SF, McManus J (1994) Application of organic car-

Editorial responsibility: Otto Kinne (Editor),

Oldendorf/Luhe, Germany bon and nitrogen stable isotope and $\mathrm{C} / \mathrm{N}$ ratios as source indicators of organic matter provenance in estuarine systems: evidence from the Tay Estuary, Scotland. Estuar Coast Shelf Sci 38:219-233

Toimazin D (1985a) Economic impact on the riverine-estuarine environment of the USSR: the Black Sea basin. Geo Journal 11:137-152

Tolmazin D (1985b) Changing coastal oceanography of the Black Sea. I: northwestern shelf. Prog Oceanogr 15:217-276

Wells RMG (1980) Invertebrate respiration. Edward Arnold, London

Weston DP (1990) Quantitative examination of macrobenthic community changes along an organic enrichment gradient. Mar Ecol Prog Ser 61:233-244

Wijsman JWM, Herman PMJ, Middelburg JJ, Soetaert K (in press) A model for early diagenetic processes in sediments of the continental shelf of the Black Sea. Estuar Coast Shelf Sci

Zaitsev YP (1993) Impacts of eutrophication on the Black Sea fauna. In: Anonymous Fisheries Council for the Mediterranean. Studies and Reviews. FAO, Rome, p 63-86

Submitted: July 13, 1998; Accepted: February 1, 1999 Proofs received from author(s): April 26, 1999 